\title{
Erratum: Reinventing tech transfer
}

Brady Huggett

Nat. Biotechnol. 32, 1184-1191 (2014); published online 5 December 2014; corrected after print 9 December 2014

In the version of this article initially published online, the name of the University of Pennsylvania president Amy Gutmann was misspelled. The error has been corrected in the HTML and PDF versions of the article.

\section{Erratum: Bring out your dead}

Nat. Biotechnol. 33, 1 (2015); published online 9 January 2015; corrected after print 9 January 2015

In the version of this article initially published, the cost of bringing a drug to market was incorrectly stated as $\$ 2.3$ billion. The correct amount, as per the Tufts study referenced in the article, is $\$ 2.56$ billion. The error has been corrected in the HTML and PDF versions of the article.

\section{Corrigendum: Linking T-cell receptor sequence to functional phenotype at the single-cell level}

\section{Arnold Han, Jacob Glanville, Leo Hansmann \& Mark M Davis}

Nat. Biotechnol. 32, 684-692 (2014); published online 22 June 2014; corrected after print 14 January 2015

In the version of this article initially published, the concentration of the V-region primers in the Online Methods section was given as $0.6 \mu \mathrm{M}$. The correct concentration is $0.06 \mu \mathrm{M}$. The error has been corrected in the HTML and PDF versions of the article.

\section{Corrigendum: Selling long life}

Christopher Thomas Scott \& Laura DeFrancesco

Nat. Biotechnol. 33, 31-40 (2015); published online 9 January 2015; corrected after print 14 January 2015

In the version of this article initially published, the caption for Figure 5 read "Pope Innocent VIII, likely the first patient to undergo parabiosis." In fact, he did not undergo parabiosis, but a blood transfusion. The caption should have read "Pope Innocent VIII died in a rejuvenation attempt in 1492." The errors have been corrected in the HTML and PDF versions of the article.

\section{Corrigendum: Status and market potential of transgenic biofortified crops}

Hans De Steur, Dieter Blancquaert, Simon Strobbe, Willy Lambert, Xavier Gellynck \& Dominique Van Der Straeten Nat. Biotechnol. 33, 25-29 (2015); published online 9 January 2015; corrected after print 14 January 2015

In the version of this article initially published, Figure 3a had three errors. The heights for bars '26' and ' 31 ' for US, Vitamin E, broccoli + tomato + potato were $\sim 7$ and $\sim 25$, respectively; the transgenic (green) value US, vitamin E, tomato was given as '24.5', but should be '40.3'. The errors have been corrected in the HTML and PDF versions of the article. 